4. Вихованець, І. Р. Граматика української мови. Синтаксис : [підручник] / І. Р. Вихованець. - К. : Либідь, 1993. - 368 с.

5. Вихованець, І. Р. Нариси 3 функціонального синтаксису української мови : [монографія] / I. Р. Вихованець. - К. : Наук. думка, 1992. - 222 с.

6. Вінтонів, М.О. Актуальне членування речення і тексту: формальні та функційні вияви : [монографія] / М. О. Вінтонів. - Донецьк : ДонНУ, 2013. 327 c.

7. Городенська, К.Г. Деривація синтаксичних одиниць : [монографія] / К. Г. Городенська. - К. : Наук. думка, 1991. - 192 с.

8. Гуйванюк, Н. В. Формально-семантичні співвідношення в системі синтаксичних одиниць : [монографія] / Н. В. Гуйванюк. - Чернівці : Рута, 1999. $-336 \mathrm{c}$.

9. Дацко, Т. Ф. Коммуникативная структура простого предложения в английском и русском языках : дисс. ... докт. филол. наук : 10.02.19 / Дацко Татьяна Федоровна. - Краснодар, 2006. - 337 с.

10. Загнітко, А. П. Теоретична граматика сучасної української мови. Морфологія. Синтаксис / А. П. Загнітко. - Донецьк : ТОВ «ВКФ «БАО», 2011. - 992 с.

11.Золотова, Г.А. Синтаксический словарь. Репертуар элементарных единиц руського синтаксиса / Г. А. Золотова. - М. : Наука, 1988. - 440 с.

12. Іваницька, Н. Л. Теоретичний синтаксис української мови. Частина перша / Н. Л. Іваницька. - Вінниця : ВДПУ ім. М. Коцюбинського, 2002. - 169 с.

13. Кульбабська, О. В. Вторинна предикація у простому реченні : [монографія] / О. В. Кульбабська. - Чернівці : Чернів. нац. ун-т, 2011. - 672 с.

14. Межов, О.Г. Типологія мінімальних семантико-синтаксичних одиниць : [монографія] / О. Г. Межов. - Луцьк : Волин. нац. ун-т ім. Лесі Українки, 2012. $-464 \mathrm{c}$.

15. Мірченко, М. В. Структура синтаксичних категорій : [монографія] / М. В. Мірченко. - Вид. 2-ге, переробл. - Луцьк : Ред.-вид. відд. «Вежа» ВДУ ім. Лесі Українки, 2004. - 393 с.

16. Сиротинина, О. Б. Лекции по синтаксису русского языка / О. Б. Сиротинина. М. : Высшая школа, 1980. - 141 с.

17. Шульжук, К. Ф. Синтаксис української мови : [підручник] / К. Ф. Шульжук. К. : Видавничий центр «Академія», 2004. - 408 с.

Стаття надійшла 20.08.2016 року

УДК 811.161.2’367.622’366.54

Василь Денисюк

(Умань, Украӥна)

\title{
ВАРІАНТНІ ФОРМИ ДАВАЛЬНОГО ВІДМІНКА ІМЕННИКІВ ЯК МОВНИЙ ЛАКМУС ПИСЕМНИХ ПАМ'ЯТОК ХVII-XVIII ст.
}

У статті проаналізовано функиіонування давального відмінка іменників чоловічого роду II відміни в літописних пам'ятках у контексті розвитку украӥнської літературної мови XVII-XVIII cm. 3'ясовано, щуо система іменника, засвідчена в 
текстах історіографічного жанру, відображає тенденцію до активного використання форм на -ови / -еви в іменниках - назвах істот і практично повну відсутність иүих флексій в іменниках - назвах неістот, щзо становить своєрідну стилістичну морфологічну ознаку сучасної украӥнської літературної мови.

Ключові слова: система словозміни іменника, українська літературна мова XVII-XVIII cm., церковнослов'янська мова, флексія, чоловічий рід, давальний відмінок.

Денисюк В. Вариантные формы дательного падежа существительных как языковой лакмус письменных памятников ХVII-XVIII вв.

В статье проанализирован дательный падеж существительных мужского рода II склонения в летописных памятниках в контексте развития украинского литературного языка XVII-XVIII вв. Установлено, что система существительного, зафиксированная в текстах историографического жанра, отражает тенденцию $к$ активному использованию форм на -ови / -еви в существительных - названиях живых существ и практически полное отсутствие этих флексий в неодушевленных существительных, что составляет своеобразный стилистический морфологический признак современного украинского литературного языка.

Ключевые слова: система словочзменения существительного, украинский литературный язык XVII-XVIII вв., церковнославянский язык, фрлексия, мужской род, дательный падеж.

Denysyuk $V$. Various dative forms of nouns as the linguistic litmus of the written records $17^{\text {th }}-18^{\text {th }}$ cc.

In this article was analyzed the functioning of dative case masculine nouns II declination in annalistic records in the context of the development of Ukrainian literary language $17^{\text {th }}-18^{\text {th }} \mathrm{cc}$.

Against the general background of the observed records we can affirm that the dative case of masculine nouns II declination has an ending -y / -ю. It is obviously that this «advantage» was provided by texts, where was used Ukrainian variant of Church Slavonic language or these texts were denoted by the influence of Russian language, not as Lingvo of Ukrainian commonalty of that time, but as the result of established restrictions and suppressions to print Ukrainian-language books. But we can see a tendency of using mostly forms -ови /-еви for subject's endings - names of human beings and practically full absence of these endings in subjects - names of non-beings, which is a stylistic morphological feature of modern Ukrainian literary language.

Keywords: noun inflection system, Ukrainian literary language $17^{\text {th }}-18^{\text {th }} \mathrm{cc}$., Church Slavonic language, inflection, masculine, dative.

Формування граматичної будови української мови становить значний інтерес для лінгвістів. Сучасні говірки є свідченням того, що цей процес ще далекий від свого завершення. Особливо це помітно у відмінковій парадигмі іменників, який у більшості відмінків має варіантні флективні форми. Актуальність статті визначається тим, що властиве мові варіювання одиниць морфології $є$ сигналом динаміки в самій мовній системі. Саме тому спостереження над функціонуванням граматичних варіантів у різножанрових писемних пам' ятках дозволяє зрозуміти зміни в системі мови, що відбувалися на різних етапах іiі розвитку. Крім того, 
вивчення пам'яток писемності української мови в такому аспекті дає змогу історикам мови пов' язати використання тих чи тих варіантних форм i кількісні параметри їх використання 3 певними стилями, відтак підкреслюючи думку про функціональну стилістику та піi актуальність у сучасній історичній лінгвістиці.

Нашу увагу привернув давальний відмінок однини іменників чоловічого роду II відміни. В останній редакції українського правопису зазначено: «У давальному відмінку однини іменники другої відміни мають закінчення -ові, -еві, -сві або -у, -ю. 1. Закінчення -ові (у твердій групі), -еві (у мішаній групі та в м'якій після приголосного), -сві (у м'якій групі після голосного та апострофа) мають іменники чол. роду: будинкові, відмінкові, директорові, дубові, майстрові, нахилові, Петрові, піонерові, робітникові, розумові; велетневі, журавлеві, каменеві, пневі, секретареві, товаришеві, махтареві; добродієві, краєві, носієві, Сергієві, солов’єві. Ці ж іменники приймають і закінчення -у (-ю): будинку, відмінку, директору й т. д.» [7, с. 86-87]. Отже, правописом закріплено варіантні форми як нормативні. У такому випадку чи не спричинить паралелізм до витіснення однієї з форм, зокрема -ові, -еві, -сві, що спостерігаємо в живому мовленні? Тим паче, що цю тенденцію активно підтримує російська мова. 3 огляду на це логічним $є$ 3'ясування питання, коли ж яке закінчення потрібно вживати і як це відображено в пам’ятках писемності.

На думку О. О. Тараненка, «варіанти мовних одиниць - це видозміни, паралельні форми існування мовної одиниці, що модифікують різні аспекти їі вираження (фонемний, морфемний або лексичний склад, місце наголосу, парадигму відмінювання, порядок слів i т. ін.), але не порушують принципу їі тотожності» [6, с. 62]. Морфологічні варіанти, як зауважує науковець, відмінні наявністю різних формотворчих афіксів та парадигмою відмінювання (дієвідмінювання) [6, с. 63]. В. М. Немченко граматичними варіантами вважає «видозміни слів, що розрізняються граматичними морфемами при збігу граматичного і лексичного значення» $[5$, c. 4$]$.

Зазначимо, що проблема становлення та функціонування відмінкових форм давального відмінка однини іменників II відміни чоловічого роду має велику історіографію як для синхронії, так і для діахронії. У контексті морфологічних особливостей писемних пам'яток специфіку вираження форм давального відмінка іменників чоловічого роду досліджували I. М. Керницький [4], Г. В. Воронич [1], Т. В. Фунікова [8] та ін. В академічному виданні «Історія української мови. Морфологія» варіантність форм давального відмінка окреслено так: «Флексія -у (-ю) це успадкована 3 давньоруської мови флексія дав. відм. однини іменників 3 колишніми основами на -б̆-, -jж; флексія -ові (-еві) - фонетично змінена давньоруська флексія дав. відм. однини іменників 3 колишньою основою 


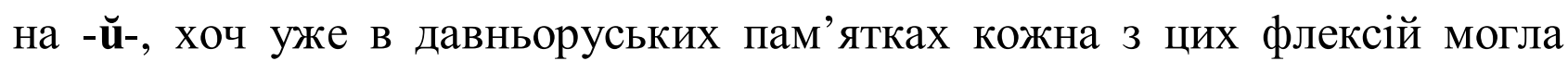

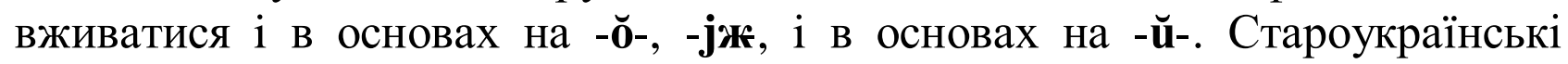
пам'ятки засвідчують вживання в дав. відм. однини іменників чол. роду флексій -у (-ю), -ови (-еви) та їі різновиду -овъ (-евъ) і зрідка -і (fl -ъ). Найпоширенішою флексією дав. відм. однини в староукраїнських пам'ятках є флексія -у (-ю). Менш поширеними в староукраїнських пам'ятках є флексії -ови (-еви), -овъ (-евъ)» [3, с. 93].

Мовознавці вказують і на територіальну диференціацію побутування флексії. Так, В. Курашкевич, проаналізувавши українські грамоти XIVXV ст. $з$ різних територій, указує, що в грамотах із північних територій функціонує тільки закінчення -у (-ю), у галицьких - засвідчено форми на -у (-ю) та -ови (-еви, -сви) [10, с. 109]. Цю ж думку підтверджує Л. Л. Гумецька, яка пише, що для пам'яток західноукраїнської мови XIVXV ст. властива наявність паралельних конкуруючих форм -ови/-у в давальному відмінку іменників чоловічого роду [2, с. 32]. В. Ярошенко в молдавських грамотах також зафіксував відмінкові форми на -у (-ю), -ови (-еви), -овы (-евы), -овъ (-евъ) [9, с. 292]. У пам'ятках ділової мови XVI ст. 3 Волині та Київщини, за спостереженнями I. М. Керницького, панівною $є$ форма -у (-ю), закінчення -ови (-еви) засвідчено спорадично [4, с. 41]. У пам' ятках XVII ст., особливо із середньої Наддніпрянщини, за даними Г. В. Воронич, типовою є флексія -ові, що вживається в іменниках - як назвах істот, так і неістот [1, с. 57]. Т. В. Фунікова довела, що в мові історіографій XVII ст. «Синопсису» та «Хроніці» Ф. Софоновича панівною флексією в давальному відмінку однини чоловічого роду $є-\mathbf{y}$ (-ю). Від назв осіб може вживатися як флексія -у (-ю), так і флексія -ови (-еви) [8, с. 29-30]. Отже, такі висновки зроблено на основі вивчення переважно ділових пам'яток. Для 3'ясування ж повноти проблеми необхідне дослідження пам'яток різних жанрів. Матеріалом нашої розвідки слугували писемні тексти літописного жанру XVII-XVIII ст., що презентують один 3 основних напрямків стильової палітри української мови окресленого періоду.

Особливістю досліджуваних пам'яток $є$, по-перше, їхнє авторство й територіальна належність, по-друге, мова. Цих два аспекти тісно переплетені, оскільки визначають використання тієї чи тієї форми. Авторами літописів були як представники козацтва, відповідно, мова таких творів насичена народнорозмовними формами, так $\mathrm{i}$ особи духовного сану, які у своїй творчості послуговувалися українським варіантом церковнослов'янської мови, де за довгий час співіснування переплелися риси двох мов - церковнослов'янської та української.

Одразу зазначимо, що у двох 3 аналізованих творів - «Короткому описі Малоросії» та Межигірському літописі - автори використали форми давального відмінка іменників чоловічого роду II відміни тільки на -у 
(-ю): -у - для іменників із твердою основою, -ю - м’якою, зокрема на й. Це стосується іменників-апелятивів - як назв неістот, так і істот, напр.: народу (МЛ, с. 96); цару московскому (МЛ, с. 98); цару турецккому (МЛ, с. 98); козаку (Описаніе, с. 214); князю Четвертенскому (Описаніе, с. 221); яссиру (Описаніе, с. 223); яссіру (Описаніе, с. 292); государю (Описаніе, с. 225-226); королю (Описаніе, с. 232); сыну (Описаніе, с. 234); боярину, столнику, митрополиту (Описаніе, с. 240); хану (Описаніе, с. 242); турчину (Описаніе, с. 272); городу (Описаніе, с. 278); сыну его, полковнику нъжинскому (Описаніе, с. 311). Використання цих же флексійних форм властиве й онімній лексиці, яку вжито як самостійно, так i $з$ апелятивним компонентом, напр.: Богу (Описаніе, с. 223); отиу его Михайлу (Описаніе, с. 219); Радулу (Описаніе, с. 237); знову Юрію вручить чинь гетманства и вручили, отдавии его въ опеку Носачу обозъному, Григорию Лесницкому судии да Ивану Виговскому писару генералныль, и постановили совњтно, дабы Выговскій, яко усвоенный дому Хмелницккого, идучи на войну, клейноти до себе принималь, а из походу ворочаясь, ему Юрию гетману отдаваль (Описаніе, с. 250); Сомку (Описаніе, с. 261); Дамяну Многогр ъиному (Описаніе, с. 269); Михайлу Ханенку, полковнику уманскому (Описаніе, с. 272); Өеодору Алексъевичу, Иоанну Алексъевичу (Описаніе, с. 275); Самуйловичу (Описаніе, с. 277); Андрею Цею, Івану Лисенку (Описаніе, с. 277); королю Яну Собецкому (Описаніе, с. 279); гетману Самуйловичу (Описаніе, с. 280); князю Голицину (Описаніе, с. 288); боярину и воеводъ Алексью Семеновичу Шеину (Описаніе, с. 295); брегадиру Стефану Веляминову (Описаніе, с. 306); Павлу Полуботку (Описаніе, с. 308); сину гетманскому, Павлу Апостолу (Описаніе, с. 312); князю Шаховскому да обозному генералному господину Якову Лизогубу (Описаніе, с. 319).

Активно автор «Короткого опису Малоросії» послуговується формою давального відмінка $з$ прийменником $\kappa$ [3, с. 413], використання якого, за даними «Словника української мови», в сучасній українській мові кваліфікують застарілим (СУМ, IV, с. 63), напр.: къ гетману Хмелницкому (Описаніе, с. 229); къ коронному гетману (Описаніе, с. 233); къ молдавскому господарю (Описаніе, с. 234); къ турецккму царю (Описаніе, с. 236); к государю царю и великому князю Алексђю Михайловичу (Описаніе, с. 239); к народу (Описаніе, с. 239); къ Нвжнину (Описаніе, с. 260); къ Чигрину (Описаніе, с. 264); къ Дорошенку (Описаніе, с. 269, 276); къ хану кримскому (Описаніе, с. 269); къ Ладиюнину (Описаніе, с. 279); къ Диъпру (Описаніе, с. 284); къ зятю своему Петру Петровичу Толстому, полковнику нъжинскому (Описаніе, с. 305); къ гетману Скоропадскому (Описаніе, с. 306); къ полку стародубовскому (Описаніе, с. 307); къ терку (Описаніе, с. 308). 
У двох пам'ятках - Гукливському літописі та «Хронології високославних ясновельможних гетьманів» - по одному разу фіксуємо форми давального відмінка на -ови, -еви, що підтверджують специфіку їхнього використання: основа на твердий - -ови, основа на шиплячий -еви, напр.: Фрсагови (ГЛ, с. 80); Барабамеви (Хронологія, с. 113). Інші випадки вживань демонструють давні традиції побутування флексії -у / -ю залежно від основи, напр.: $\boldsymbol{\epsilon} \boldsymbol{n}^{\tilde{c}} \boldsymbol{n y}$ Коледїю Єзовъику (ГЛ, с. 76); $\boldsymbol{\epsilon n} \boldsymbol{n}^{\tilde{n} \boldsymbol{y}}$ Андрею Бачи скїи (ГЛ, с. 76); Петру Конашевичу Сагайдачному, Дорошу Коцкевичу, Михайлу Дороченку, Тимофею Арандаренку, Леонтію Бубновскому, Богдану Хмелницкому, Иоанну Виговскому (Хронологія, с. 114); къ цару (Хронологія, с. 116); Павлу Тетерь (Хронологія, с. 116); императору Петру Первому (Хронологія, с. 119); къ пресвњтльйшему Всероссійскому престолу (Хронологія, с. 121); архіепископу Рафаилу (Хронологія, с. 121); господину Гендрикову, полномочному министру (Хронологія, с. 123).

Інші досліджувані тексти також ілюструють активне використання обох флексійних форм. Однак закінченню -ови / -еви автори віддають перевагу у випадку використання іменника, що позначає істоту, напр.: -ови: послови (КЛ, 5, с. 111; ЛБ, с. 65); Гетманови (КЛ, 5, с. 111; ЧЛ, с. 6); блгодариша бгови (ЛГМ, с. е)); Любартови (ЛБ, с. 64); Писимунтови (ЛБ, с. 64); Троянови (ЛБ, с. 64); Дорошенкови (ЛД, с. 232); турчинови (ЛД, с. 233; ЛЛ, с. 32); Ханенкови (ЛД, с. 234); цесарови (ЛД, с. 234; ЧЛ, с. 19); сынови (ЧЛ, с. 9); народови (ЧЛ, с. 9); татаринови (ЧЛ, с. 14); Алексеови (ЧЛ, с. 16); солтанови (ЛЛ, с. 13; ЧЛ, с. 8); мона тарирови

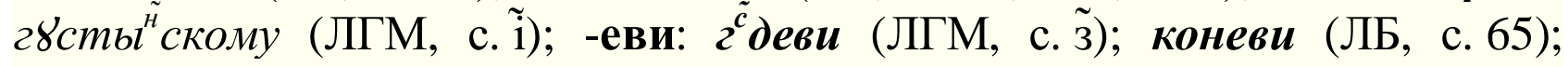
цареви (ЛБ, с. 65; ЧЛ, с. 24); кролеви (ЛБ, с. 66; ЧЛ, с. 26); королеви (ЛД, с. 231; ЛЛ, с. 45); Москалеви (ЧЛ, с. 12); Юрасеви (ЛЛ, с. 19); Государеви

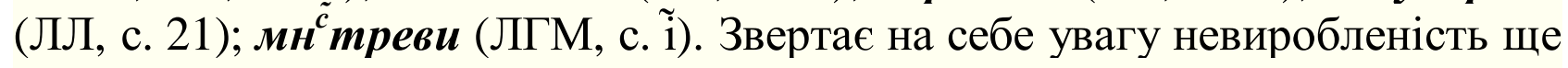
чітких критеріїв у вживанні флексії в іменниках на -р, як це спостерігаємо, наприклад, у лексемах цар, иесар, монастир, государ. Це ж стосується й іменників на шиплячий та й, для яких нормативним є закінчення -еви, напр.: папежюви (ЛБ, с. 64; ЧЛ, с. 5); Тугай-беови (ЧЛ, с. 8); Кочубеови (ЧЛ, с. 24).

Крім уже традиційних, принаймні у графічному оформленні, варіантів закінчення -ови / -еви, аналізований матеріал засвідчує і такі форми: -овы: Веславовы (ЛБ, с. 63); Заславовы (ЛБ, с. 63); Святополковы (ЛБ, с. 63); Ияроморовы (ЛБ, с. 63); Дорошенковы (ЛД, с. 234); -ові: Всеволдові (ЛБ, с. 63); -овظ: ляховъ (ЛД, с. 231); Дорошенковъ (ЛД, c. 233).

У досліджуваних пам'ятках фіксуємо форми давального відмінка 3 прийменником противу/противъ, що 3 XIII ст. поступово почали 
витіснятися формами родового відмінка [3, с. 441], напр.: против стрысви (КЛ, 2, с. 115); против цесарови Фридрихови (ЛБ, с. 64).

Акцентуємо й на тому, що поодинокими випадками репрезентовано використання флексії -ови / -еви в іменниках - назвах неістот: юрсагови

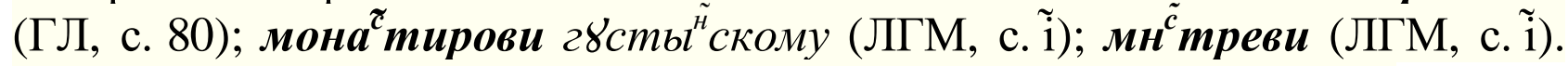
Слушною видається думка Г.В. Воронич, яка зазначає, що «у таких іменниках при виборі закінчення -ові відіграє роль звуження лексичного значення, в якому конкретизуються найменування осіб, живих істот» [1, с. 57]. Справді, зафіксовані нами іменники демонструють семантичні зрушення в напрямку від більш загального значення (край, монастир) до конкретнішого (жителі краю, мешканці монастиря), що стало визначальним у виборі флексії -ови / -еви для утворення таких форм давального відмінка.

Нерегламентованим було використання поряд кількох іменників чоловічого роду у формі давального відмінка. Більшість контекстів засвідчує, що автори надавали перевагу однаковим закінченням, напр.: кгізю Василю (КЛ, 2, с. 118); Алексею Михаиловичу, цุару московскому (ЧЛ, с. 11); Августови Сасови, королеви полскому (ЧЛ, с. 22); королеви полскому Августови (ЧЛ, с. 24); цару Петру (ЧЛ, с. 25, 27); атаманови запорозскому Кость Гордъенкови (ЧЛ, с. 26); Петру Алексъевичу, цару (ЧЛ, с. 27); пану гетману Ілльчу Скоропадскому было (ЧЛ, с. 28); полковнику Павлу Полуботку (ЧЛ, с. 32); генералу моэору и гвардіи преображенского полку маэору Андрею Івановичу Ушакову (ЧЛ, с. 33); стария їюаса̀ф8 (ЛГМ, с.

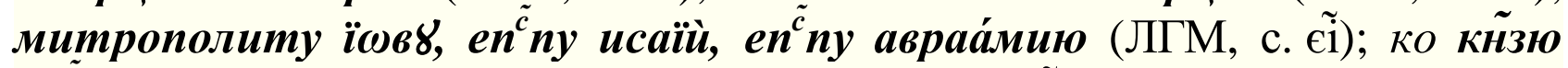

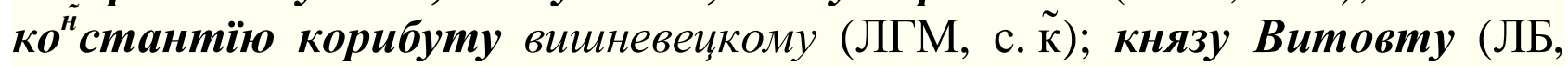
с. 65); кролю Жигимонту (ЛБ, с. 66); П(а)ну Б(о)zу (ЛБ, с. 67); королевичу Владиславу (ЛЛ, с. 5); отцу его Михайлу (ЛЛ, с. 7); къ великому царю Алексію Михайловичу, самодерюниу всероссійскому (ЛЛ, с. 14); къ Асламъ Кгерею, хану крылскому (ЛЛ, с. 15); Юрасю, сыну своему младольтнему (ЛЛ, с. 17); Ивану Виговскому, писарю енералному войсковому (ЛЛ, с. 18); Михаилу Ханенку, полковнику уманскому (ЛЛ, с. 27); гетману Самойловичу (ЛЛ, с. 29); королю Яну Сабъскому (ЛЛ, с. 30); Петру Дорошенку, гетману чигиринскому (ЛЛ, с. 30); къ Дорошенку, тестю своему (ЛЛ, с. 33); боярину князю Галицььну (ЛЛ, с. 35); козаку тому, Свириду Перебенди (ЛЛ, с. 43); Августу королю полскому (ЛЛ, с. 43); къ зятю своему Петру Толстому, полковнику НЪжинскому (ЛЛ, с. 55); сенатору и генералу-лейтенанту Семену Ивановичу Нарыикину (ЛЛ, с. 62); князю Андрею Трофимовичу Борятынскому (ЛЛ, с. 64); запорожскому козаку Іосифу Волку (ЛЛ, с. 65); къ генералу фельтмаршалу Каролю Фонъ-Миниху (ЛЛ, с. 68). 
Одиничними випадками презентовано спроби використання різних флексій для забезпечення милозвучності, проте таку диференціацію автори здійснювали непослідовно, напр.: сынови своему тимошу (ЛЛ, с. 12); пйу Пвтрови Кунашввичови Сагаидачному (КЛ, 5, с. 112); королеви полскому Яну Казимирови (ЧЛ, с. 13). В останній редакції правопису на цю особливість звернено увагу у примітці: «Коли в тексті зустрічається поряд кілька іменників чол. роду у формі давального відмінка однини, то для уникнення одноманітних відмінкових закінчень слід спочатку вживати закінчення -ові, -еві (-сві), а тоді - -у (-ю): Симоненкові Василю Андрійовичу, Леонідові Миколайовичу Іваненку, добродієві бригадиру» [7, с. 86].

Інші приклади демонструють уживання флексії -у / -ю в іменниках назвах істот і неістот, напр.: Радивилу (ЧЛ, с. 10); цару (ЧЛ, с. 11); Павлу Тетерь (ЧЛ, с. 14); Юрію Хмелницүкому (ЧЛ, с. 13); къ государю (ЧЛ,

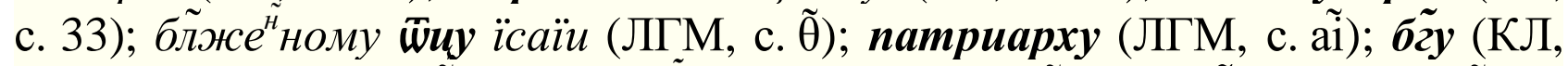

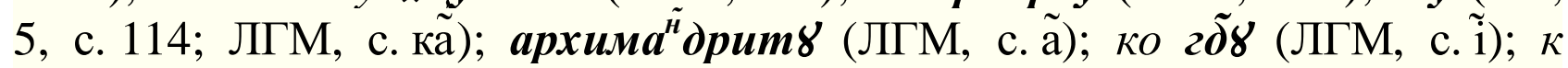
Новугороду (КЛ, 2, с. 117); к Витовту (КЛ, 2, с. 117); манастыру (КЛ, 2, с. 114); ко Судомиру и Завифвосту (КЛ, 5, с. 104); папєюну (КЛ, 5, с. 104); ко стцу (КЛ, 2, с. 114); ко Западу (КЛ, 5, с. 107); ку Смоленъску (ЛБ, с. 66); п(а)ну (ЛБ, с. 65); кресту (ЛБ, с. 71); гетману (ЛЛ, с. 3); козаку (ЛЛ, с. 3); Павлюку (ЛЛ, с. 6); народу, сыну, браму (ЛЛ, с. 12); хану (ЛЛ, с. 14); къ народу малороссійскому (ЛЛ, с. 14); Юрасю (ЛЛ, с. 16, 19); Ханенку (ЛЛ, с. 27); Дорошенку (ЛЛ, с. 30); къ Чигрину (ЛЛ, с. 30); къ Шліонску (ЛЛ, с. 35); къ Государямь Царямъ Іоанну и Петру Алексіевичамь (ЛЛ, с. 37); къ роду христіанскому (ЛЛ, с. 42); къ шведскому королю (ЛЛ, с. 47); къ Дону (ЛЛ, с. 51); къ Днъиру (ЛЛ, с. 31); къ военному походу (ЛЛ, с. 63). Уживання ойконіма Умань у формі давального відмінка доводить, що первинно це був іменник чоловічого роду, напр.: к Уманю (ЛД, с. 234).

Отже, на загальному тлі обстежених пам'яток можна констатувати, що в давальному відмінку однини іменників чоловічого роду II відміни переважає закінчення -у / -ю. Очевидним $\epsilon$ те, що таку «перевагу» забезпечили тексти, позначені використанням українського варіанта церковнослов'янської мови чи впливом російської мови не як лінгви тодішнього українського соціуму, а як наслідок запроваджених обмежень і заборон друкувати україномовні книги. Однак спостерігаємо тенденцію до активного використання форм на -ови / -еви в іменниках - назвах істот і практично повну відсутність цих флексій в іменниках - назвах неістот, що становить своєрідну стилістичну морфологічну ознаку сучасної української літературної мови. Перспективним вважаємо дослідження особливостей вираження форм давального відмінка іменників чоловічого роду в пам'ятках інших жанрів. 


\section{СПИСОК УМОВНИХ СКОРОЧЕНЬ}

ГЛ - Гукливський літопис (Угроруські літописні записки) // Записки Наукового товариства імені Шевченка. - 1911. - Т. 106. - Кн. 4. - С. 73-82.

КЛ - Київський літопис першої чверті XVII ст. // Український історичний журнал 1989. - № 2. - С. 107-120; 1989. - № 5. - С. 103-114.

ЛБ - Мицик Ю., о. Літопис Яна Бінвільського / Ю. Мицик // Наукові записки НаУКМА. Історичні науки. - 2002. - Т. 20. - Ч. 2. - С. 60-77.

ЛГМ - Летопись Густынского монастыря // Чтения в Обществе истории и древностей российских. - 1848. - № 8. - 76 с.

ЛД - Мыцык Ю.А. «Літописец» Дворецких - памятник украинского летописания XVII в. / Ю. А. Мыцык // Летописи и хроники 1984. - М., 1984. - С. 219234.

ЛЛ - ЛЪтописецъ или описаніе краткое знатнъйшихъ дъйствъ и случаевъ, что въ которомъ году дъялось въ Украини малороссійской обоихъ сторонъ ДнЊпра и кто именно когда Гетманомъ былъ козацкимъ (1506-1737) // Сборник летописей, относящихся к истории Южной и Западной Руси. - К., 1888. - С. 1-69.

МЛ - Межигорская льтопись (1608-1700) // Сборник летописей, относящихся к истории Южной и Западной Руси / под. ред. В. Б. Антоновича. - К., 1888. - С. 95-100.

Описаніе - Краткое Описаніе Малороссіи // Лътопись Самовидца по новооткрытымъ спискамъ съ приложеніемъ трехъ малороссійскихъ хроникъ: Хмельницкой, «Кратного Описанія Малороссіи» и «Собранія Историческаго». - К., 1878. - С. 209-319.

СУМ - Словник української мови : в 11 т. / за ред. І. К. Білодіда. - К. : Наук. думка, 1970-1980. - Т. 1-11.

Хронологія - Хронологія высокославныхъ ясневельможныхъ гетмановъ (15061765) // Южнорусские летописи, открытые и изданные Н. Белозерским. - К., 1856. T. 1. - C. 107-124.

ЧЛ - Черниговская летопись по новому списку (1587-1725) и Коломацкие челобитные / оттиск из Киевской Старины ; изд. Ал. Лазаревского. - Киев, 1890. $44 \mathrm{c}$.

\section{СПИСОК ВИКОРИСТАНОЇ ЛІТЕРАТУРИ}

1. Воронич, Г. В. Форми давального відмінка на -ові / -у / Г. В. Воронич // Культура слова. - К. : Наук. думка, 1983. - Вип. 24. - С. 56-58.

2. Гумецкая, Л.Л. К вопросу о языке молдавских грамот XIV-XV вв. / Л. Л. Гумецкая // Otázky dějin střední a východní Evropy. Vyd. 1. - Brno, 1971. C. 25-35.

3. Історія української мови: Морфологія / С. П. Бевзенко, А. П. Грищенко, Т. Б. Лукінова та ін. - К. : Наук. думка, 1978. - 539 с.

4. Керницький, І. М. Система словозміни в українській мові: на матеріалах пам' яток XVI ст. / I. М. Керницький. - К. : Наук. думка, 1967. - 288 с.

5. Немченко, В. Н. Грамматическая вариативность слова в современном русском языке и литературная норма : учебное пособие / В. Н. Немченко. - Нижний Новгород : Изд-во Нижегородского ун-та, 1998. - 282 с. 
6. Тараненко, О.О. Варіанти мовних одиниць / О.О. Тараненко // Українська мова: енциклопедія / редкол. В. М. Русанівський, О. О. Тараненко (співголови), М. П. Зяблюк та ін. - К. : Вид-во «Українська енциклопедія» ім. М. П. Бажана, 2004. - С. 62-63.

7. Український правопис / Ін-т мовознавства ім. О. О. Потебні НАН України, Ін-т української мови НАН України. - К. : Наук. думка, 2015. - 288 с.

8. Фунікова, Т. В. Становлення флексій давального та місцевого відмінків іменників чоловічого роду в українській літературній мові XVII ст. (на матеріалі «Синопсису» та «Хроніки» Ф. Софоновича) / Т. В. Фунікова // Вісник Харківського національного університету імені В. Н. Каразіна. Серія Філологія. № 994. Вип. 64. - Харків, 2012. - С. 28-34.

9. Ярошенко, В. Українська мова в молдавських грамотах XIV-XV ст. / В. Ярошенко // Збірник Комісії для дослідження старої української мови. - Т. 1. - K., 1931. - C. 247-338.

10. Kuraszkiewicz, W. Gramoty halicko-wolyńskie XIV-XV wieku / W. Kuraszkiewicz. - Kraków : Skłąd Główny : Gebethner i Wolff, 1934. - 173 p.

Стаття надійшла 07.04.2016 року

УДК $81 ’ 246.2+81 ’ 255.2$

Надежда Никитина

(Минск, Республика Беларусь)

\section{О СТАТУСЕ АВТОРСКОГО ПЕРЕВОДА В КОНТЕКСТЕ СИТУАЦИИ БИЛИНГВИЗМА}

В статье рассматриваются проблемы статуса авторского перевода, его связи с мышлением и поведением билингвальной языковой личности, устанавливаются причины обращения авторов к самостоятельному переводу своих произведений, а также факт правомерности изменений, вносимых в текст оригинала при авторском переводе. Предпринята попьтка обобщить существующие взгляды на лингвистическую сущность, коммуникативную и художественную значимость авторского перевода. В статье представлен иирокий обзор отечественных $u$ зарубежных источников по проблемам изучения авторского перевода.

Ключевые слова: авторский перевод, билингвизм, билингвальная языковая личность, внутренний конфликт, интерференция, коммуникация.

\footnotetext{
Нікітіна Н. Про статус авторського перекладу в контексті ситуації білінгвізму.

У статті розглядаються проблеми статусу авторського перекладу, його зв'язки з мисленням та поведінкою білінгвальної мовної особистості, встановлюються причини звернення авторів до самостійного переведення свойх творів, а також факт правомірності змін, внесених у текст оригіналу при авторському перекладі. Зроблена спроба узагальнити існуючі погляди на лінгвістичну сутність, комунікативну та художню значимість авторського перекладу. У статті
} 